\title{
PENGARUH FORMALIN TERHADAP MUKOSA YEYUNUM TIKUS PUTIH (Rattus norvegicus strain wistar)
}

\author{
Thontowi Djauhari NS*, Desy Andari, Nurmasari*
}

\begin{abstract}
Background : Cancer of intestinum tenue are frequently present comparatively late in their natural history as it has less symptoms and diagnostic difficulty. Most of these tumors are found at surgery indicated for other diagnosis or intestinal obstruction with widespread metastatic. Formalin usually misused especially in food industry and if it's consumed could cause the deviation of the body.

Purpose : Prove the effect of formalin on Wistar rat's jejunal mucous (Rattus norvegicus strain wistar).

Research Methode: The design of the study was pure experimental using The Posttest Control Group Design. Samples were Wistar Rats divided into 4 groups. Group I as a control which is not given formalin, and the other groups were given formalin dosed 20 ppm, 40 ppm, and 80 ppm.

Result and discussion: The results shown that formalin caused byperplasia, bypertrophy, atrophy and inflammation (ANOVA $p=$ 0.000). The changes of rat's jejunal mucous were probably caused by the binded DNA by the protein that affect the normal genetic expression.

Conclusions: The study proved that formalin caused the changes of Wistar rat's jejunal mucous, and further study was needed to support clinical application.
\end{abstract}

Key Words: Cancer of intestinum tenue; formalin; intestinum tenue

\begin{abstract}
Abstrak
Latar Belakang : Kanker intestinum tenue merupakan salab satu bentuk kanker yang sulit diketabui karena kurang menimbulkan gejala dan sering ditemukan pada saat pembedahan dengan indikasi penyakit lain atau obstruksi intestinum dalam keadaan yang sudah metastasis. Formalin banyak disalahgunakan terutama di bidang industri makanan, yang apabila dikonsumsi dapat menyebabkan kelainan pada tubuh.

Tujuan : Membuktikan pengaruh formalin terbadap mukosa yeyunum tikus putih (Rattus norvegicus strain wistar).

Metode Penelitian : Penelitian ini merupakan eksperimental murni, dengan rancangan The Posttest Control Group Desain. Sampel penelitian adalah tikus putih strain wistar yang dibagi dalam 4 kelompok. Kelompok I sebagai kontrol tanpa pemberian formalin dan kelompok lainnya diberi formalin dosis 20 ppm, 40 ppm, dan 80 ppm.

Hasil \& Pembahasan : Hasil yang didapat dari penelitian adalab pemberian formalin dapat menyebabkan hiperplasia, hipertropi, atropi dan radang (ANOVA $\mathrm{p}=0.000)$. Pengaruh perubahan mukosa yeyunum diduga karena terikatnya DNA oleh protein sehingga mengganggu ekspresi genetik yang normal.
\end{abstract}

Kesimpulan : Pada penelitian ini dapat disimpulkan bahwa pemberian formalin dapat menyebabkan perubahan mukosa yeyunum tikus putih strain wistar, dan diperlukan penelitian lanjutan yang menunjang kepentingan klinik.

Kata kunci : Kanker intestinum tenue; formalin; intestinum tenue.

\footnotetext{
* Staff Pengajar Pada Fakultas Kedokteran

Universitas Muhammadiyah Malang

** Mahasiswi Pada Fakultas Kedokteran

Universitas Muhammadiyah Malang
} 


\section{Latar Belakang}

Intestinum tenue terdiri dari duodenum, yeyunum dan ileum. Yeyunum merupakan organ yang mempunyai fungsi absorbsi paling utama. Kanker intestinum tenue merupakan salah satu bentuk kanker yang sulit diketahui karena biasanya kurang menimbulkan gejala. Meskipun angka kejadian kanker tersebut sangat rendah, namun angka kejadian tersebut semakin meningkat seiring dengan banyaknya makanan yang mengandung zat karsinogenik. Jenis kanker yang paling sering ditemukan yaitu adenokarsinoma, limfoma, sarkoma, dan karsinoid (Elsevier, 2003).

Etiologi dari kanker intestinum tenue belum diketahui secara pasti, namun diduga dipengaruhi oleh keadaan pre-kanker, seperti peradangan kronis (Crohn disease), serta dipengaruhi oleh makanan yang mengandung bahan karsinogen seperti formalin. Pada penelitian yang pernah dilakukan, dilaporkan bahwa formalin pada hewan percobaan dapat menyebabkan kanker sedangkan pada formalin diduga mengandung asam format yang dapat menyebabkan kanker pada manusia (Zbar, 2008; WHO, 2007).

Formalin banyak disalahgunakan terutama di bidang makanan. Balai Badan Penelitian Obat dan Makanan (BB-POM) mengumumkan bahwa berdasarkan hasil penelitian tahun 2007 terhadap 700 sampel produk makanan yang diambil dari Pulau Jawa, Sulawesi Selatan dan Lampung awal bulan ini, 56\% diantaranya mengandung formalin (Marssy, 2007). Sedangkan hasil investigasi dan pengujian laboratorium yang dilakukan di Jakarta, ditemukan sejumlah produk pangan seperti ikan asin, mi basah, mi ayam super, tahu, kwe tiaw, dan ikan segar menggunakan formalin sebagai pengawet dengan konsentrasi antara 3-400 ppm (Judarwanto, 2000; Suyatna, 2005).

Berdasarkan acuan kesehatan di Inggris, paparan maksimum formalin yaitu $2 \mathrm{ppm}$ atau 2 $\mathrm{mg} / \mathrm{l}$. Sedangkan Amerika Serikat (AS) menetapkan paparan maksimum untuk jangka panjang 1 ppm dan jangka pendek $2 \mathrm{ppm}$. Sedangkan menurut OSHA (Occupational Safety and Health Administration) batas yang bisa ditoleransi oleh tubuh adalah 0,75 ppm, dan menurut NIOSH (The National Institute for Occupational Safety and Health) adalah 0,016 ppm dan menurut ACGIH (The American Conference of Governmental Industrial Hygienists) adalah $0,3 \mathrm{ppm}$ (Santoso, 2008 ).
Pada penelitian terdahulu secara in vivo pada binatang coba tikus dan anjing yang dipapar formalin peroral ditemukan adanya keadaan patologis berupa ulserasi, papillary hiperplasia dan hiperkeratosis permukaan lambung, atropik gastritis, serta ulserasi dan hiperplasia dari mukosa kelenjar lambung (WHO, 2001).

Penelitian tentang pengaruh formalin pada yeyunum belum pernah dilakukan, padahal yeyunum merupakan organ yang mempunyai fungsi absorbsi paling utama. Sehingga timbul pertanyaan apakah formalin subakut dapat menyebabkan perubahan pada sel mukosa yeyunum.

\section{Rumusan Masalah}

Apakah pemberian formalin peroral subakut dapat menyebabkan lesi pada mukosa yeyunum tikus putih (Rattus norvegicus strain wistar)?

\section{Tujuan Penelitian}

Tujuan Umum

Membuktikan pengaruh pemberian formalin peroral subakut terhadap mukosa yeyunum tikus putih strain wistar (Rattus norvegicus strain wistar)

Tujuan Khusus

- Membuktikan pemberian formalin peroral subakut terhadap mukosa yeyunum tikus putih strain wistar (Rattus norvegicus strain wistar) dapat menyebabkan kerusakan plika sirkularis

- Membuktikan pemberian formalin peroral subakut terhadap mukosa yeyunum tikus putih strain wistar (Rattus norvegicus strain wistar) dapat menyebabkan kerusakan vili intestinal.

- Membuktikan pemberian formalin peroral subakut terhadap mukosa yeyunum tikus putih strain wistar (Rattus norvegicus strain wistar) dapat menyebabkan terjadinya peningkatan jumlah sel adaptasi (sel hiperplasia, hipertropi, dan atropi)

- Membuktikan pemberian formalin peroral subakut terhadap mukosa yeyunum tikus putih strain wistar (Rattus norvegicus strain wistar) dapat menyebabkan peningkatan sel radang 
96 Vol. 7 No 15 Desember 2011

\section{MetodologiPenelitian}

Penelitian ini adalah penelitian eksperimental dan rancangan penelitian yang digunakan adalah The Posttest Control Group Design.

\section{Tempat dan Waktu Penelitian}

Tempat : Laboratorium Farmakologi Fakultas Kedokteran Universitas Muhammadiyah Malang

Waktu : 4 Minggu

\section{Populasi}

Populasi dari penelitian ini adalah seluruh tikus putih strain wistar (Rattus norvegicus strain wistar).

\section{Sampel}

Sampel yang digunakan adalah tikus putih strain wistar (Rattus norvegicus strain wistar) berjenis kelamin jantan dengan berat 180-200 gram dan berusia 23 bulan dengan kondisi sehat yang ditandai dengan gerakan yang aktif dan mata yang jernih.

\section{Estimasi Besar Sampel}

Pada penelitian ini terdapat 4 kelompok perlakuan yaitu satu kelompok kontrol dan tiga kelompok perlakuan (tikus yang diinduksi dengan formalin dosis 20, 40, dan $80 \mathrm{ppm}$ ). Dosis tersebut berdasarkan penelitian terdahulu dan telah dibuktikan melalui studi eksplorasi secara subakut (4 minggu) terhadap tikus putih strain wistar (Rattus norvegicus strain wistar).

Estimasi besarnya sampel yang digunakan pada penelitian ini adalah sesuai dengan rumus berikut:

$\begin{array}{cl}(\mathrm{t}-1)(\mathrm{p}-1) & \text { eH } 15 \\ (\mathrm{t}-1)(4-1) & \text { eH } 15 \\ 3 \mathrm{t}-3 & \text { eH15 } \\ 3 \mathrm{t} & \text { eH18 } \\ \mathrm{t} & \text { eH6 (Supranto, 2007) }\end{array}$

Keterangan :

$\mathrm{P}=$ Perlakuan

$\mathrm{t}=$ Jumlah sampel per perlakuan

Jadi jumlah sampel keseluruhan yang digunakan dalam penelitian ini adalah 24 ekor tikus.
24 ekor tikus dibagi menjadi 4 kelompok dan tiap kelompok terdiri dari 6 ekor tikus :

- Kelompok 1 : Tidak dipapar formalin (kontrol)

- Kelompok 2 : Dipapar formalin dengan dosis $20 \mathrm{ppm} /$ hari

- Kelompok 3 : Dipapar formalin dengan dosis $40 \mathrm{ppm} /$ hari

- Kelompok 4 : Dipapar formalin dengan dosis $80 \mathrm{ppm} / \mathrm{hari}$

\section{Bahan dan Instrumen Penelitian}
1. Formalin
2. Air

\section{Variabel dan Definisi Operasional}

\section{a. Variabel Bebas}

o Dosis Formalin (0, 20, 40, dan 80 ppm)

\section{b. Variabel Tergantung}

o Jumlah sel yang hiperplasia, hipertropi, atropi, dan sel radang

\section{Definisi Operasional}

- Formalin adalah larutan formaldehida dalam air, dengan kadar antara 10\%-40\%. Yang digunakan adalah formalin dengan konsentrasi 20, 40 dan 80 ppm.

- Sel dikatakan hiperplasia apabila terjadi pertambahan sel dan susunan sel terkesan tidak rapi (normalnya di basal)

- Sel dikatakan hipertropi apabila ukuran sel menjadi lebih besar dari sel normal dan diikuti oleh membesarnya inti sel

- Sel dikatakan atropi apabila ukuran sel menjadi lebih kecil dari sel normal dan diikuti oleh mengecilnya inti sel

- Sel radang yang dimaksud yaitu sel radang akut (PMN) yang terdiri dari neutrofil, basofil, dan eosinofil

- Organ yeyunum yang diambil yaitu yeyunum bagian proximal yaitu $1 \mathrm{~cm}$ dari batas duodenum-yeyunum sepanjang 3-5 cm

- Metode subakut merupakan suatu pemberian perlakuan secara berulang pada hewan coba dalam waktu 4 minggu (darmansjah, 2000). 


\section{Cara Kerja}

\section{Pembagian Kelompok Tikus}

Tikus yang digunakan sebanyak 24 ekor yang terbagi menjadi 4 kelompok dan tiap kelompok terdiri dari 6 ekor tikus

- Kelompok 1 : Tidak dipapar formalin (sebagai kontrol)

- Kelompok 2 : Dipapar formalin dengan dosis $20 \mathrm{ppm} / \mathrm{hari}$

- Kelompok 3 : Dipapar formalin dengan dosis $40 \mathrm{ppm} /$ hari

- Kelompok 4 : Dipapar formalin dengan dosis $80 \mathrm{ppm} /$ hari

\section{Adaptasi}

Proses adaptasi hewan coba dalam kandang selama 7 hari dengan tujuan agar tikus menyesuaikan diri terhadap lingkungan yang baru.

\section{Pemaparan Formalin}

Setiap pemaparan menggunakan formaldehida dalam bentuk cair dengan bantuan sonde.

\section{Pembuatan Sediaan Histopatologi}

Pembuatan sediaan histologi yeyunum dilakukan dengan cara:

1. Tikus dimatikan dengan metode dekapitasi, yaitu dengan cara mematahkan leher tikus

2. Perut tikus dibedah untuk diambil yeyunumnya. Pengambilan organ yeyunum dilakukan dengan cara dipotong bagian proximalnya.

3. Irisan yeyunum diletakkan pada tabung organ dan fiksasi dengan formalin 10\% selama 24 jam

4. Dilakukan dehidrasi dengan merendam pada alkohol bertingkat, yaitu pada konsentrasi 50\%, 70\%, 95\% dan 2 kali alkohol absolut masing - masing selama 30 menit

5. Dilakukan clearing dengan menggunakan alkohol dan xilol dengan perbandingan alkohol : xilol (3:1, $1: 1,1: 3)$ dan dua kali xilol murni masing - masing selama 60 menit.
6. Dilakukan proses infiltrasi dengan xilol dan parafin dengan perbandingan xilol : parafin $3: 1,1: 1,1: 3$ dan 1 kali parafin murni selama 1 jam jam pada suhu $46^{\circ} \mathrm{C}-52^{\circ} \mathrm{C}$

7. Dilakukan blocking dengan parafin keras pada suhu $46^{\circ} \mathrm{C}-52^{\circ} \mathrm{C}$ selama 1 jam

8. Kemudian dipotong dengan mikrotom yang berukuran 3-5 milimikron dan potongan direkatkan pada kaca obyek

9. Dipanaskan pada suhu 46-52 $\mathrm{C}$ di dalam inkubator selama 24 jam

10.Dilakukan deparafinisasi yaitu dengan perendaman dengan xilol 2 kali alkohol absolut 95\%, 85\%, 70\%, 50\%, 30\% dan $\mathrm{H}_{2} \mathrm{O}$ masing - masing selama 3 menit

11. Dilakukan pewarnaan Hematoxilin Eosin dengan langkah - langkah sebagai berikut :

- Pemberian Haris Hematoxilen selama 15 detik

- Eosin staining selama 15 - 20 menit

- Dehidrasi pada alkohol bertingkat 50\%, $70 \%, 85 \%$, 95\%, dan 2 kali alkohol absolut

- Pemberian xilol selama 5 menit

- Mounting menggunakan perekat entelan

- Panaskan pada suhu 46 - 52 $\mathrm{C}$ di dalam inkubator selama 24 jam

- Diamati pada mikroskop

\section{Pengamatan Hasil}

- Organ yeyunum diamati secara langsung perubahannya

- Sediaan diamati dengan mikroskop cahaya dengan pembesaran 100X dan 400X untuk mengamati perubahan struktur histologis mukosa pada 5 lapang pandang dengan menggunakan mikrometer

\section{Metode Analisa Data}

Menggunakan uji ANOVA dengan uji kebebasan menggunakan SPSS 11 dan dilakukan analisa korelasi regresi. 


\section{$98 \quad$ Vol. 7 No 15 Desember 2011}

\section{Hasil Penelitian dan Analisa Data}
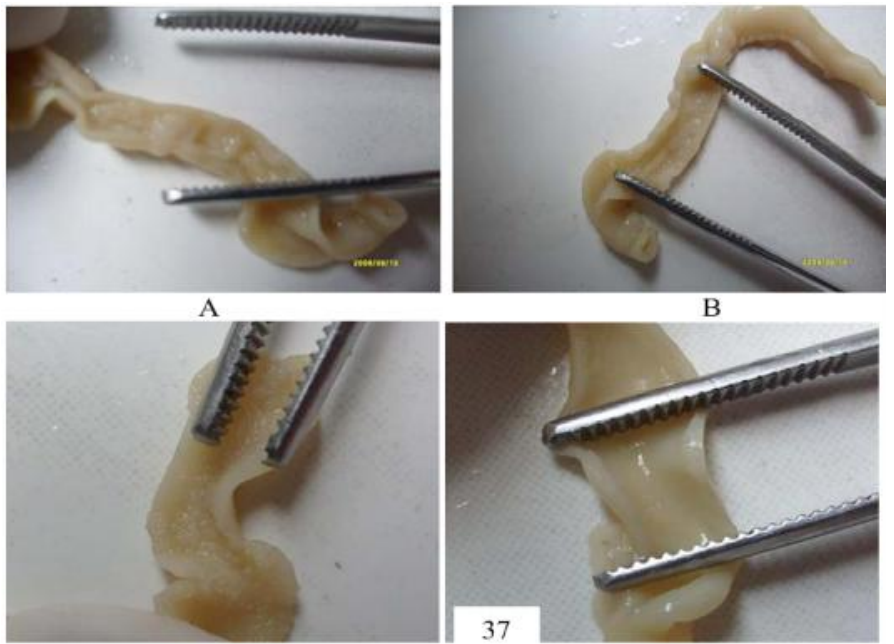

B

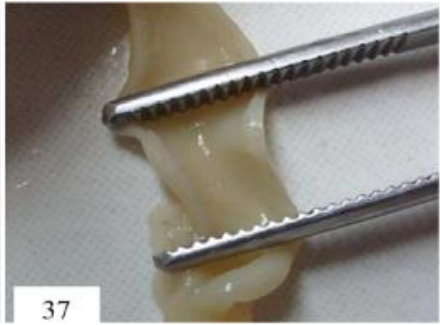

1. Gambaran Mikroskopik yeyunum tikus

Gambar 1 Gambaran makrokopis yeyunum tikus. A. kelompok 1 (formalin 0 ppm), yeyunum tikus tampak normal dengan plika sirkularis masih utuh. B. Kelompok 2 (formalin $20 \mathrm{ppm}$ ), yeyunum tikus tampak abnormal dengan plika sirkularis yang rusak. C. Kelompok 3 (formalin $40 \mathrm{ppm}$ ), yeyunum tikus tampak abnormal dengan plika sirkularis yang rusak dan semakin menipis. D. Kelompok 4 (formalin 80 ppm), yeyunum tikus tampak abnormal dengan hilangnya plika sirkularis (lumen licin dan tidak tampak plika sirkularis).
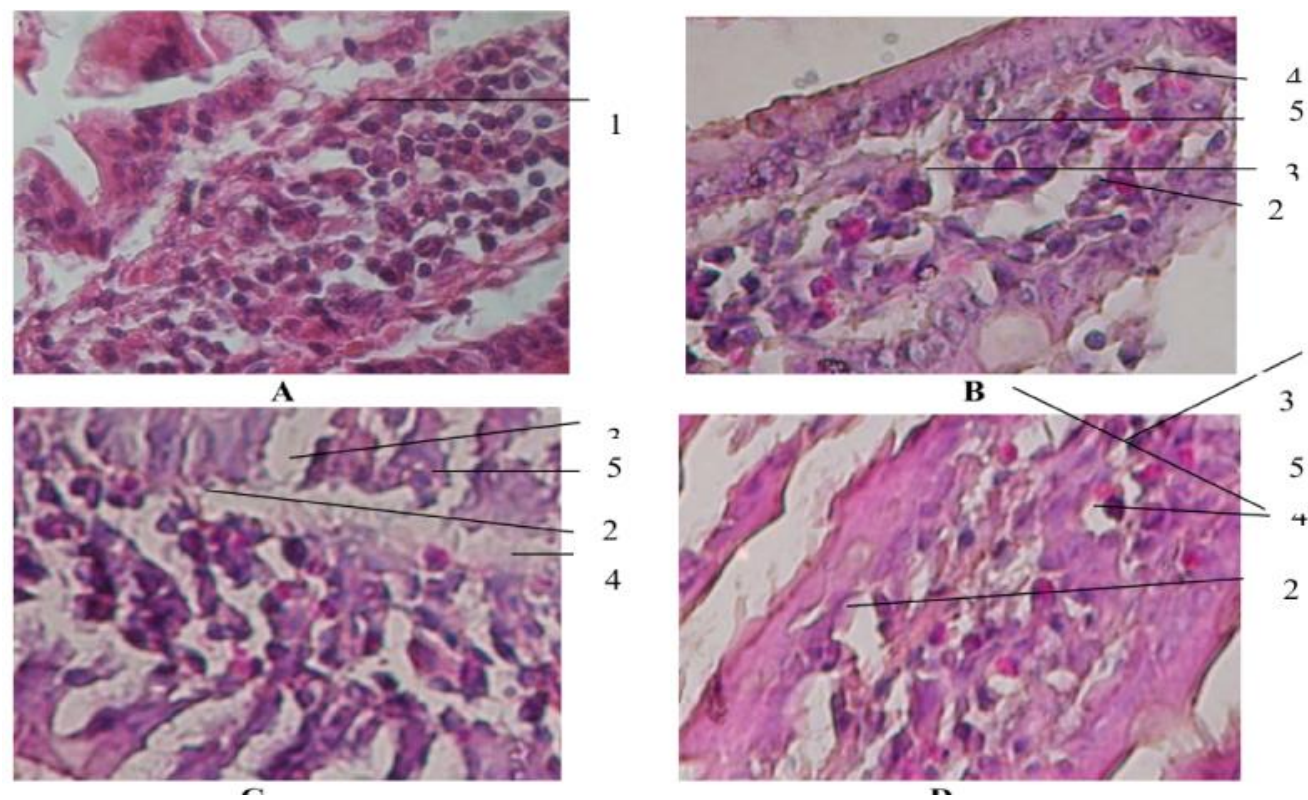

\section{Gambaran Mikroskopis Yeyunum Tikus}

Gambar 2. Gambaran mikroskopis yeyunum tikus. A. Kelompok 1 (formalin 0 ppm), gambaran epithel columnar simplex tampak normal. B. Kelompok 2 (formalin $20 \mathrm{ppm}$ ), tampak adanya sel hiperplasia, hipertropi, atropi, dan muncul sel radang. C. Kelompok 3 (formalin 40 ppm), tampak adanya sel hiperplasia, hipertropi, atropi, dan muncul sel radang dengan derajat kerusakan lebih besar dari kelompok sebelumnya. D. Kelompok 4 (formalin $80 \mathrm{ppm}$ ), tampak adanya sel hiperplasia, hipertropi, atropi, dan muncul sel radang. (1) Sel epitel columnar simplex pada mukosa yeyunum. (2) Sel hiperplasia. (3) Sel hipertropi. (4) Sel atropi. (5) Sel radang. 


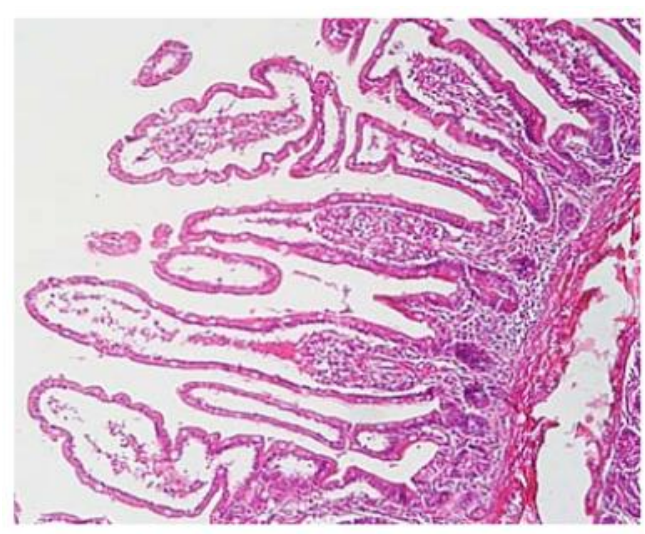

A

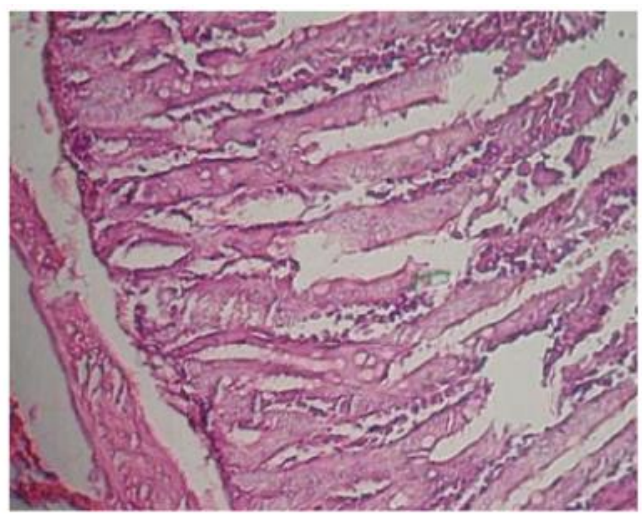

B

3.Gambaran Mikroskopis Yeyunum Tikus

Gambar 3. Gambaran mikroskopis yeyunum tikus. A. Kelompok 1 (formalin 0 ppm), yeyunum tikus tampak normal dengan vili intestinalis masih utuh. B. Kelompok 2 (formalin $20 \mathrm{ppm}$ ), yeyunum tikus tampak vili intestinalis yang mulai rusak. C. Kelompok 3 (formalin $40 \mathrm{ppm}$ ), yeyunum tikus tampak atropi vili intestinalis parsial. D. Kelompok 4 (formalin $80 \mathrm{ppm}$ ), yeyunum tikus tampak atropi vili intestinalis subtotal.

\section{Data Hasil Penelitian dengan Menggunakan Alat Bantu Mikrometer}

Berdasarkan hasil penelitian tentang "Pengaruh formalin terhadap mukosa yeyunum tikus putih strain wistar" yang menggunakan 4 kelompok perlakuan (kontrol, pemberian formalin $20 \mathrm{ppm}$, pemberian formalin $40 \mathrm{ppm}$, pemberian formalin $80 \mathrm{ppm}$ ) tampak pada tabel 5.1

Tabel 1 Tingkat Kerusakan Yeyunum (\%) Terhadap Berbagai Perlakuan

\begin{tabular}{cclrrr}
\hline DOSIS & \multirow{2}{*}{$\mathbf{N}$} & JENIS SEL & TOTAL & RERATA & \multirow{2}{*}{ SD } \\
\hline $0 \mathrm{ppm}$ & 6 & HIPERPLASIA & 1.62 & 0.27 & \pm 0.24 \\
& & HIPERTROPI & 1.47 & 0.25 & \pm 0.12 \\
& & 2.065 & 0.34 & \pm 0.33 \\
& & 11.8 & 1.97 & \pm 0.33 \\
\hline $20 \mathrm{ppm}$ & 6 & RADANI & 166.69 & 27.78 & \pm 1.23 \\
& & HIPERPLASIA & 181.91 & 30.32 & \pm 0.95 \\
& & HIPERTROPI & 104.11 & 17.35 & \pm 1.64 \\
& & ATROPI & 147.29 & 24.55 & \pm 3.12 \\
\hline $40 \mathrm{ppm}$ & 6 & RADANG & 150.31 & 25.05 & \pm 1.07 \\
& & HIPERPLASIA & 187.03 & 31.17 & \pm 0.48 \\
& & HIPERTROPI & 106.78 & 17.8 & \pm 0.17 \\
& ATROPI & 155.88 & 25.98 & \pm 1.01 \\
\hline $80 \mathrm{ppm}$ & 6 & RADANG & 142.24 & 23.71 & \pm 0.36 \\
& & HIPERPLASIA & 176.98 & 29.5 & \pm 0.29 \\
& HIPERTROPI & 100.57 & 16.76 & \pm 0.36 \\
& ATROPI & 180.2 & 30.03 & \pm 0.49 \\
\hline
\end{tabular}




\section{Sel Hiperplasia}

\section{Hiperplasia}

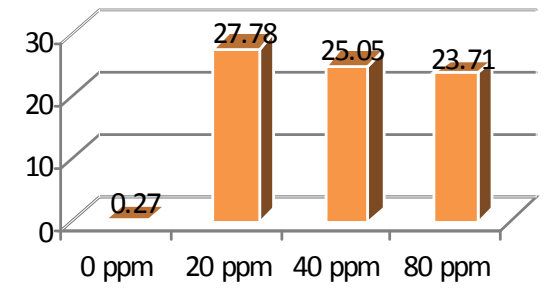

\section{Gambar 4.}

Berdasarkan gambar 4. menunjukan bahwa sel hiperplasia paling banyak terdapat pada kelompok 2 (formalin $20 \mathrm{ppm}$ ) yakni $27.78 \%$ dan yang paling sedikit terdapat pada kelompok 1 (formalin 0 ppm) yakni $0.27 \%$. Dari grafik diatas juga terlihat bahwa jumlah sel hiperplasia cenderung naik dengan semakin besar pemberian dosis, namun menurun pada pemberian dosis $40 \mathrm{ppm}$ dan semakin menurun pada peningkatan dosis.

Berdasarkan uji ANOVA diketahui adanya perbedaan yang sangat signifikan $(\mathrm{Sig}=0.000<0.010)$ antar kelompok perlakuan, dimana kelompok 2 (formalin dosis $20 \mathrm{ppm}$ ) memberi efek hiperplasia paling tinggi $(\overline{\mathrm{x}}=27.78)$.

Berdasarkan uji korelasi terlihat ada hubungan antara dosis yang diberikan terhadap hiperplasia yang sangat signifikan $(r=0.585$; $\operatorname{Sig}=0.003<$ 0.010).

Berdasarkan uji regresi terlihat ada pengaruh antara dosis yang diberikan terhadap hiperplasia yang sangat signifikan $(\mathrm{F}=11.471 ; \mathrm{Sig}=0.003<0.010)$. Besar pengaruh dosis terhadap hiperplasia $\left(\mathrm{r}^{2} \mathrm{x}\right.$ 100) $=34.3 \%$

\section{Sel Hipertropi}

\section{Atropi}

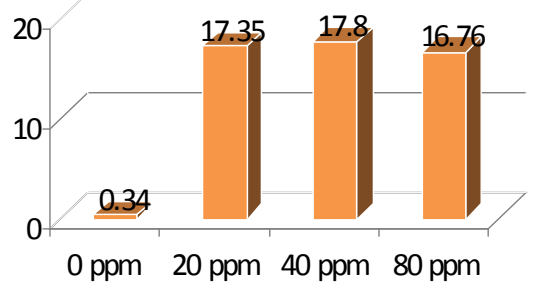

Gambar 5
Berdasarkan gambar 5. menunjukan bahwa sel hipertropi paling banyak terdapat pada kelompok 3 (formalin $40 \mathrm{ppm}$ ) yakni $31.17 \%$ dan yang paling sedikit terdapat pada kelompok 1 (formalin 0 $\mathrm{ppm}$ ) yakni $0.25 \%$. Dari grafik diatas juga terlihat bahwa jumlah sel hipertropi cenderung naik dengan semakin besar pemberian dosis, namun menurun pada pemberian dosis $80 \mathrm{ppm}$.

Berdasarkan uji ANOVA diketahui adanya perbedaan yang sangat signifikan $(\mathrm{Sig}=0.000<0.010)$ antar kelompok perlakuan, dimana kelompok 3 (formalin dosis $40 \mathrm{ppm}$ ) memberi efek hipertropi paling tinggi $(=31.17)$.

Berdasarkan uji korelasi terlihat ada hubungan antara dosis yang diberikan terhadap hipertropi yang sangat signifikan $(r=0.660 ;$ Sig $=0.000<0.010)$.

Berdasarkan uji regresi terlihat ada pengaruh antara dosis yang diberikan terhadap hipertropi yang sangat signifikan $(\mathrm{F}=17.024$; Sig $=0.000<0.010)$. Besar pengaruh dosis terhadap hipertropi $\left(r^{2} \times 100\right)=43.6 \%$

\section{Sel Atropi}

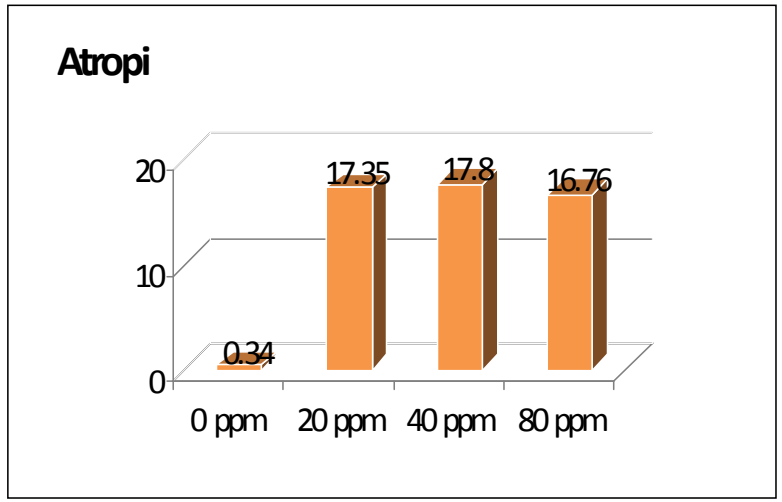

\section{Gambar 6}

Berdasarkan gambar 6. menunjukan bahwa sel atropi paling banyak terdapat pada kelompok 3 (formalin $40 \mathrm{ppm}$ ) yakni $17.80 \%$ dan yang paling sedikit terdapat pada kelompok 1 (formalin 0 $\mathrm{ppm}$ ) yakni $0.34 \%$. Dari grafik diatas juga terlihat bahwa jumlah sel atropi cenderung naik dengan semakin besar pemberian dosis namun menurun pada pemberian dosis 80 ppm.

Berdasarkan uji ANOVA diketahui adanya perbedaan yang sangat signifikan (Sig $=0.000<$ 0.010) antar kelompok perlakuan, dimana kelompok 3 (formalin dosis $40 \mathrm{ppm}$ ) memberi efek atropi paling tinggi $(=17.80)$. 
Berdasarkan uji korelasi terlihat ada hubungan antara dosis yang diberikan terhadap atropi yang sangat signifikan $(r=0.653$; $\operatorname{Sig}=0.001<0.010)$.

Berdasarkan uji regresi terlihat ada pengaruh antara dosis yang diberikan terhadap atropi yang sangat signifikan $(\mathrm{F}=16.317$; Sig $=0.001<0.010)$. Besar pengaruh dosis terhadap atropi $\left(\mathrm{r}^{2} \mathrm{x} 100\right)=42.6 \%$

\section{Sel Radang}

\section{Radang}

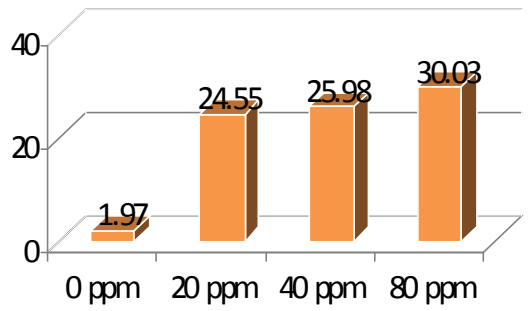

\section{Gambar 7}

Berdasarkan gambar 7. menunjukan bahwa sel radang paling banyak terdapat pada kelompok 4 (formalin $80 \mathrm{ppm}$ ) yakni 30.03\% dan yang paling sedikit terdapat pada kelompok 1 (formalin 0 ppm) yakni 1.97\%. Dari grafik diatas juga terlihat bahwa jumlah sel radang cenderung naik dengan semakin besar pemberian dosis.

Berdasarkan uji ANOVA diketahui adanya perbedaan yang sangat signifikan (Sig $=0.000<$ 0.010) antar kelompok perlakuan, dimana kelompok 4 (formalin dosis $80 \mathrm{ppm}$ ) memberi efek radang paling tinggi $(=30.03)$.

Berdasarkan uji korelasi terlihat ada hubungan antara dosis yang diberikan terhadap radang yang sangat signifikan $(\mathrm{r}=0.797$; $\mathrm{Sig}=0.000<0.010$ ).

Berdasarkan uji regresi terlihat ada pengaruh antara dosis yang diberikan terhadap radang yang sangat signifikan $(\mathrm{F}=38.406 ; \mathrm{Sig}=0.000<0.010)$. Besar pengaruh dosis terhadap radang $\left(\mathrm{r}^{2} \times 100\right)=$ $63.6 \%$

\section{PEMBAHASAN}

Penelitian ini merupakan penelitian eksperimental dengan desain the postest only control group dengan tujuan membuktikan pengaruh pemberian formalin peroral subakut terhadap mukosa yeyunum tikus putih.

Hasil penelitian ini dilakukan uji kualitatif dan uji kuantitatif. Pada uji kualitatif dilakukan dengan mengamati yeyunum tikus secara makroskopik dan mikroskopik. Hasil pengamatan makroskopik kelompok kontrol terlihat tidak ada kerusakan pada mukosa yeyunum tikus. Kemudian melalui pemeriksaan mikroskopis dapat dilihat juga tidak terdapat kerusakan dari sel epitel dari mukosa yeyunum.

Pengamatan makroskopik dan mikroskopis pada perlakuan 2,3 , dan 4 (pemberian formalin 20 ppm, 40 ppm, dan 80 ppm) dapat dilihat bahwa terjadi lesi yang berupa penipisan plika sirkularis dan atropi vili intestinalis. Dengan semakin besar dosis yang diberikan, maka plika sirkularis semakin menipis dan atropi vili intestinalis semakin meningkat. Hal ini disebabkan formalin dapat menembus sawar mukosa sehinggga dapat mengakibatkan cedera jaringan yang mengakibatkan sel memberi respon berupa adaptasi (hiperplasia, hipertropi, dan atropi) dan munculnya sel radang. Adaptasi sel tersebut secara tidak langsung dapat mengakibatkan perubahan bentuk vili. Sedangkan cedera pada jaringan dapat menyebabkan produksi chemoattractants neutrofil seperti leukotrien, interleukin, dan mengaktivasi komponen komplemen. Sebagai respon, neutrofil keluar dari kapiler dan menginfiltrasi mukosa subepitel dan berpindah menembus epitel intestinum dengan cara merusak junctional complex antara sel-sel epitel. Hal ini dapa menyebabkan perubahan bentuk vili intestinalis menjadi atropi dan pada pengamatan makroskopis tampak plika sirkularis yang menipis (Bowen, 2001).

Selanjutnya pengamatan secara mikroskopik pada perlakuan 2, 3, dan 4 (pemberian fomalin dosis 20 pm, 40 ppm, dan 80 ppm) didapatkan sel hiperplasia, hipertropi, atropi, dan sel radang. Hal tersebut merupakan respon jaringan terhadap agen kimia, dalam hal ini formalin, yang dapat mengakibatkan cedera pada jaringan. Cedera jaringan dapat terjadi pada sel-sel parenkim (cedera langsung) dan jaringan interstitial (cedera tak langsung). Akibatnya dapat terjadi degenerasi sel 
parenkim dan interstitial bahkan bisa terjadi nekrosis (Chandrasoma, 2006). Selain itu diduga karena formalin dapat menyebabkan terikatnya DNA oleh protein, sehingga mengganggu ekspresi genetik yang normal (WHO, 2005).

Munculnya sel hiperplasia, hipertropi, atropi, dan radang merupakan suatu mekanisme adaptasi sel terhadap lingkungan, yang dalam hal ini respon terhadap cedera kimia yang disebabkan formalin. Adaptasi sel bisa fisiologik maupun patologik. Hiperplasia terjadi bila sel-sel suatu jaringan terangsang untuk menjalani pembelahan sel sehingga menambah jumlah sel (Chandrasoma, 2006). Dalam hal ini sel hiperplasia meningkat akibat pengaruh pemberian dosis $20 \mathrm{ppm}$, namun pada pemberian dosis yang lebih besar lagi (formalin $40 \mathrm{ppm}$ ) justru mengalami penurunan. Hal ini diduga sel hiperplasia pada kelompok 3 (formalin $40 \mathrm{ppm}$ ) sudah mulai metaplasia. Demikian juga pada dosis 80 ppm.

Hipertropi disebabkan oleh peningkatan jumlah sitoplasma organel di dalam sel. Pada selsel sekretorik, aparatus sintetik - mencakup retikulum endoplasma, ribosom, dan zona golgi menjadi menonjol. Pada sel kontraktil seperti serabut otot, terdapat penambahan ukuran miofibril sitoplasma (Chandrasoma, 2006). Dalam hal ini sel hipertropi cenderung meningkat akibat pengaruh pemberian dosis yang semakin besar, namun pada pemberian dosis yang lebih besar lagi (formalin 80 ppm) justru mengalami penurunan. Hal ini diduga sel yang hipertropi sudah maksimal sehingga sel menjadi lisis.

Atropi merupakan berkurangnya jumlah sitoplasma dan jumlah organel sitoplasma dan jumlah organel sitoplasma serta biasanya terkait dengan penurunan metabolisme. Organel yang berdegenerasi diambil vakuola lisosom untuk menjalani degradasi enzimatik (autofagi). Membran organel yang tersisa sering terkumpul di dalam sitoplasma sebagai pigmen lipofusin coklat. Pengurangan jumlah sel disebabkan oleh ketidakseimbangan proliferasi dan kematian sel dalam jangka waktu lama (Chandrasoma, 2006). Dalam hal ini sel atropi cenderung meningkat akibat pengaruh pemberian dosis yang semakin besar, namun pada pemberian dosis yang lebih besar lagi (formalin $80 \mathrm{ppm}$ ) justru mengalami penurunan. Terjadinya sel atropi pada penelitian ini diduga karena adanya (1) hilangnya pasokan darah akibat dari terjepitnya kapiler oleh sel yang hipertropi maupun hiperplasia sehingga terjadi anoksia jaringan; (2) adanya 'tekanan' dari sel sekitar yang mengalami hipertropi maupun hiperplasia sehingga terjadi hipoksia jaringan setempat

Sel radang muncul akibat respon selular yang dilakukan tubuh karena adanya agen asing. Peradangan dalam hal ini adalah peradangan akut yang ditandai dengan emigrasi aktif sel-sel radang dari darah ke arah cedera (Chandrasoma, 2006). Dalam hal ini sel radang cenderung meningkat terhadap pemberian dosis formalin yang semakin besar. Keadaan tersebut sesuai dengan teori. Apabila setiap ada agen asing maka tubuh akan selalu memberikan respon.

Dari berbagai fakta yang ditemukan pada penelitian ini dan melalui kajian teoritik, maka hipotesa tentang pemberian formalin peroral subakut dapat menyebabkan lesi pada mukosa yeyunum tikus putih (Rattus norvegicus strain wistar) terbukti, namun masih memerlukan penelitian lebih lanjut untuk menentukan mekanisme yang sebenarnya dari formalin dalam menyebabkan perubahan mukosa yeyunum dan peningkatan rentang dosis sehingga didapatkan dosis minimal yang mulai menimbulkan efek terhadap yeyunum. Penelitian ini hanya sebatas lapisan mukosa, sehingga diperlukan penelitian lebih lanjut mengenai lapisan dibawahnya.

\section{KESIMPULAN}

1 Formalin dapat menyebabkan kerusakan plika sirkularis berupa penipisan plika.

2 Formalin dapat menyebabkan atropi vili intestinalis.

3 Formalin dapat menyebabkan sel mukosa yeyunum mengalami adaptasi berupa hiperplasia, hipertropi, dan atropi. Serta munculnya sel radang

4 Dosis formalin yang dapat menyebabkan perubahan sel mukosa yeyunum tikus adalah 20 ppm, 40 ppm, dan 80 ppm. Dibuktikan ada pengaruh antara sel hiperplasia $\left(\mathrm{R}^{2}=34.3\right)$, hipertropi $\left(\mathrm{R}^{2}=43.6\right)$, atropi $\left(\mathrm{R}^{2}=42.6\right)$, dan radang $\left(\mathrm{R}^{2=}\right.$ 63.6)) yaitu semakin besar dosis yang diberikan maka perubahan sel semakin banyak. 


\section{SARAN}

1 Perlu adanya penelitian lanjutan dengan meningkatkan rentang dosis formalin yang digunakan sehingga didapatkan dosis minimal dari formalin yang mulai menimbulkan perubahan struktur mukosa yeyunum.

2 Perlu dilakukan penelitian lanjutan untuk mengetahui pengaruh formalin terhadap kapiler, submukosa, muskularis dan lapisan serosa yeyunum sehingga akan diketahui bagaimana pengaruh formalin terhadap yeyunum secara keseluruhan.

\section{DAFTAR PUSTAKA}

Bretscher A, Weber K et al. 2002. Usus; dalam Buku Ajar Histologi Edisi 12. Hal 552-568. EGC. Jakarta

Chandrasoma, Parakrama dan Taylor, Clive R. 2006. Ringkasan Patologi Anatomi Edisi 2. EGC. Jakarta. Hal 1; 37-38; 231 233; 522-523

Elsevier. 2003. Primary Tumors of Jejunum and Ileum as a Cause of Intestinal Obstruction. (online) (http:// journals.elsevierhealth.com diakses tanggal 1 Juli 2008)

Judarwanto, Widodo dr.spA. 2007. Pengarub Formalin Bagi Sistem Tubuh. (online) (http:// www.puterakembara.org/archives 8/ 000066.shtml diakses tanggal 20 November 2007)

Marssy, Rad. 2007. Bahaya Kandungan Formalin Pada Makanan. (online) (http:// www.radmarssy.wordpress.com/ 2007/02/06/bahaya-kandunganformalin-pada-makanan/ diakses tanggal 5 Maret 2008)

Santoso, SP. 2008. Pencetus Kanker. (online) (http:// www.geocities.com/santososp diakses tanggal 29 April 2008)

Suyatna, Frans D MD, PhD, SpFK. 2006. Awas Formalin Di Plastik Makanan. (online) (http://www.gizi.net diakses tanggal 29 April 2008)

World Health Organization. 2001. Formaldehyde. (online) (http://www.who.org diakses tanggal 1 November 2007)
World Health Organization. 2005. Formaldehyde in drinking-water. Background document for development of WHO Guidelines for drinking-water quality. Geneva (online) http://ww w. wh o. int/ water sanitation health/dwq/ chemicals/formaldehyde130605.pdf diakses tanggal 25 Februari 2008)

World Health Organization. 2007. Formaldehyde. (online) (http://www.inchem.org/ documents/cicad40.htm diakses tanggal 1 November 2007)

Zbar, AP prof. 2005. West Indian Medical Journal Carcinoma of th Jejunum with Multideposit Peritoneal Seeding, Resection and Intraperitoneal Chemotherapy. (online) (http://www.scielo.org diakses tanggal 1 Juli 2008) 